\title{
BUSINESS WOMEN AND THE LEGAL PROTECTION IN VORTEX OF THE GLOBAL ECONOMY
}

\author{
${ }^{1}$ Nur Sulistyo Budi Ambarini \\ Faculty of Law, Bengkulu University \\ Bengkulu, Indonesia \\ ambarini@unib.ac.id \\ ${ }^{2}$ Tito Sofyan \\ Faculty of Law, Bengkulu University \\ Bengkulu, Indonesia \\ tito.sofyan@gmail.com
}

\author{
${ }^{3}$ Edra Sadmaidi \\ Faculty of Law, Bengkulu University \\ Bengkulu, Indonesia \\ Edra_fhunib@yahoo.com
}

\begin{abstract}
According to article 33 paragraph 3 Constitution of Indonesian Republic 1945, Indonesia's natural wealth is controlled by the state and is used for the welfare of the people. With economic activity every citizen can utilize the natural resources. The activities of micro, small and medium enterprises are among the supports of the national economy. Number of MSMEs is about 57.9 million, covering micro business 98.82 percent, small business 1.09 percent, and medium enterprises 0.09 percent, and 60 percent of the actors are women. Generally household businesses that do not have legality and have various limitations. Legal research with socio-legal approach of research to women micro business actors in the field of fishery showed no government siding. There are 70 percent or approximately 39 million people are women from 56 million people involved in fishing activities. Approximately 47 percent work in the processing and marketing of catches with an average majority working 17 hours per day.lt is also recognized by the Food and Agriculture Organization (FAO). In Indonesia the juridical existence of women fishermen has not gained state recognition and has not been accommodated in the Fisheries Act. In practice, the imbalance of legal relationships in fishery product transactions results in the powerlessness of women fishermen as business actors in business.Therefore, it needs guidance and empowerment as well as recognition of the existence of women fishermen as business actors to provide legal protection through strengthening institutional and government policies both at the central and regional levels.

Keywords-Business Women; Legal Protection; Global Economy.
\end{abstract}

\section{INTRODUCTION}

Since the beginning of independence Indonesia is a unitary state of the Republic of Indonesia which aims to protect the nation, the country and the land of the blood of $\mathrm{RI}$, prospering the community, educating the nation and maintaining world order. This is stated in the Preamble of the 1945 Constitution of the Republic of Indonesia Alenia IV. To achieve these objectives pursuant to Article 1 Paragraph (3) of the 1945 Constitution of the Republic of Indonesia, Indonesia is a state of law that bases the life of the nation and state in law. In this context constitutionally every Indonesian citizen has the right and position before the law as stipulated in Article 27 paragraph (1) of the 1945 Constitution. Similarly, for the welfare of nation's life, Article 27 paragraph (2) guarantees the right of every citizen to obtain work or strive to live worthy of his dignity and worth. But in everyday life in society the facts are different, there are still many citizens who have not got their rights related in terms of legal protection or job or business opportunity.

Indonesia as a welfare state based on Article 33 of the 1945 Constitution of the Republic of Indonesia adopts a mixed economy system. In this case the state intervenes in the management of the national economy. The State controls the natural resources and resources that are important for the livelihood of the people, but also provides opportunities for the people to use in improving the welfare. Every citizen can cultivate natural resources through economic activities based on the principle of kinship and joint effort. Therefore, both individuals and groups can utilize natural resources in accordance with the principles set forth in Article 33 Paragraph (4) of the 1945 Constitution of the Republic of Indonesia. 
Indonesia's national economy is basically supported by small and medium-sized micro enterprises (MSMEs), which are increasing in number. In 2014 there are approximately 57.9 million units, covering micro business 98.82 percent, small business 1.09 percent, and medium enterprises 0.09 percent. Not only in Indonesia MSMEs has become the backbone of the economy, but also in ASEAN there are about 88,8$99,9 \%$ effort in the form of MSMEs with labor absorption 51,7 - 97,2\%. In the last five years UMKM has contributed to the gross domestic product from $57.84 \%$ to $60.34 \%$, with labor absorption of $96.99 \%-97.22 \%$. However, the contribution of MSMEs in Indonesia to the global supply chain is only $0.8 \%$. According to Ina Primiana (Professor of Economics Faculty of Padjadjaran University Bandung), most of MSMEs actors do not have information and access to global market.1

Women are mostly engaged in micro and small businesses whose numbers in Indonesia continue to increase from year to year. Therefore, structurally, MSMEs occupy important positions and roles as well as potentials that need to be explored and developed in the national economy in the global era. 2 In addition has proved able to survive and become a driver after the economic crisis, 3 as well as research results Supriyanto (2006) said that MSMEs can be a solution to poverty in Indonesia.4 However, in the midst of global economic flows and high competition also required a strong micro small business strong to be able to face global and regional challenges. Therefore, it is necessary to increase the competitiveness of products in order to compete in regional and global markets. In addition, Government policy is also required to prepare regulations that can provide protection for SMEs most of the perpetrators are women.

As quoted by Giwo Rubiyanto Wiyogo (Chairman of Kowani), citing data from the Association of Indonesian Guarantee Companies (Asippindo) that 80 percent of Indonesian SMEs managed by women. 5 In general, SMEs engaged in informal and formal business, as well as in the field of utilization of natural resources and labor intensive, such as agriculture, fisheries, plantation, food crops, livestock, trade, forestry, home industry, tourism and others. 6 Sectorally about 60 percent of the total micro-small enterprises are businesses engaged in agriculture, animal husbandry, forestry and fisheries.7Similarly women business actors are engaged in these areas and are generally more focused on areas related to trade and processing such as food, handicrafts and clothing that are household and conventional industries.

The contribution of women in the national economy is considerable. In addition to reducing poverty and labor absorption to overcome unemployment, also in an effort to equitable public welfare. But it can not be denied that the economic activities undertaken by women, including small and medium scale micro enterprises still have many limitations. It is not only about capital, business management, but also juridical concerning the recognition and protection of the law. Most of the efforts undertaken by women do not have legality, so from the legal aspect also has various weaknesses. Therefore it is necessary to get attention especially in its development in the era of economic globalization.

\section{METHODS}

This study is a non-doctrinal law by using the approach of socio-legal research. This research requires the primary data is collected through field research with observations and interviews. Secondary Data was collected through the study of literature, in the form of legal materials and nonlaw that can support problem solving research. The Analyzed the data were qualitatively

\section{Concept of Legal Protection}

Women entrepreneurs are economic actors generally located on the scale of small and medium-sized micro enterprises. In the activities of MSMEs as economic entities there are legal relationships that need to be regulated by law. In accordance with its function as a protection of human rights law has a goal and objectives to be achieved. The main purpose of the law is to create an orderly order of society, to create order and balance, so that human interests can be expected to be protected.8 According to Satjipto Rahardjo, the presence of law in society to integrate and coordinate interests that can collide with one another. Organizing those interests is done by limiting and protecting the interests concerned. 9

In the context of Indonesia, the concept of legal protection by Philipus M Hadjon10 is termed 'the protection of people's law', which in principle is the recognition and protection of the dignity of human beings originating from Pancasila and the principles of the rule of law based on Pancasila. Legal protection is the act of providing protection to legal subjects as a supporter of rights and obligations. It can be said to be the embodiment of a legal function that can provide justice, order, certainty, usefulness and peace. This can be given 
in the form of a legal instrument that is both preventive and repressive.

According Soediman Kartohadiprodjo11 overall rule of law as a positive legal system imbued the values of the five principles of Pancasila and called Pancasila Law. The goal of Pancasila law is to realize order and orderliness, peace and justice formulated by the term 'Pengayoman (Protection)', which is to protect human beings both in the sense of passive and active. Passive is to prevent arbitrary and violation of rights. Actively involves efforts to create conditions and encourage people to constantly humanize themselves.

In relation to the legal protection of women especially in the field of fisheries has been agreed in the International Convention on the Convention on the Elimination of All Forms of Discrimination Against Women (CEDAW) and Voluntary Guidelines to Ensure Sustainable Small Scale Fisheries in the context of Food Security and Poverty Reduction (Voluntary Guidelines for Securing Sustainable Small-Scale Fisheries in the Context of Food Security and Poverty Eradication), on state obligations. Both international agreements contain the basic rights that must be met by the state are (1). Right to work; (2). Right to good health and safety services; (3). Right to access and obtain proper education; (4). Right to social security; (5). Right to training and education (formal and informal); (6). The right to organize and establish cooperatives as a platform for the struggle for equality; (7). The right to participate in all community activities; (8). Right to get fishery credits, marketing services, and technology; (9). Land rights; and (10). Right to get a house, sanitation, electricity, clean water, and transportation. In addition, the state has the obligation of the state to treat preferably to the salt fishermen / cultivators / farmers to obtain basic rights as follows: adequate housing: basic sanitation safe and hygienic; safe drinking water for individual and household use; Energy sources; Savings, credit and investment schemes Recognize the existence and role of women in the small-scale fishery value chain, especially post-harvest; Create conditions free of discrimination, crime, violence, sexual harassment, corruption and abuse of power Abolition of forced labor; Facilitate the participation of women in work: GED equality refers to CEDAW; and Technology development for women working in small-scale fisheries sector.

\section{Legal Protection Against Women Business Actors In Global Economy}

Economic development is an effort to improve the nation's living standards in order to achieve national goals to improve the welfare of the Indonesian nation. Therefore, based on Article 27 Paragraph (2), the State shall give guarantee to every citizen to work or try to live a decent life. Everyone shall be given an opportunity to be able to carry out economic activities by utilizing Indonesia's natural wealth as stipulated in Article 33 Paragraph (3) of the Constitution State of the Republic of Indonesia 1945. Economic activity may be carried out individually or in groups or together as the provisions of Article 33 paragraph

(1) stating that the economy is constituted as a joint effort based on kinship. Utilization of natural resources can be done every citizen to be able to improve the welfare of himself and his family. It can involve many parties including women.

One of the many economic activities involving women is the fishery sector. Fishery is an economic activity that includes pre-production, production, processing, and marketing activities conducted in a binis system. Fisheries as natural resources which in the effort of its utilization can not be separated from woman role especially in coastal area. From the socio-cultural aspect one of the characteristics that characterize coastal communities according to Kusnadi (2009) is the division of sex-based labor is the sea is the domain of men and land is the realm of women.12 The involvement of women in the mainland in general in the secondary sector is the processing industry of fishery products as both business actors and laborers. Fish processing units in Indonesia are mostly MSMEs. Number of Fish Processing Units (UPI) until 2015 there are 61,603 units covering large scale 718 units and small and medium micro scale 60,885 units. 13

KIARA information data center, in May 2014 recorded at least 56 million people engaged in fishing activities ranging from fishing, processing and marketing of fishery products. Of these 70 percent or 39 million people are women fishermen. Then in 2015 also recorded at least 48 percent of fishermen's family income is the contribution of female fishermen who work 17 hours per day. Another fact shows that 47 percent of fishermen women work in the processing and marketing of fishery products. 14

Women in the skipjack tuna business group have an important role, ranging from the process 
of availability of raw materials, the provision of equipment and materials processing, washing, cleavage, installation of bamboo (stapled), the process of curing up, and marketing of tuna fish, women.15 The results of the author's research in Bengkulu, many fishermen women engaged in dry or salted fish processing business. Mostly in the group (fish processor), lowly educated, using traditional \& simple equipment, small micro scale, without legality, bulk marketing and retail in local market (district / province), and there is no continuous guidance and assistance, has not been able to access the Financing Pattern of SMEs of Dry Fish Processing Business in Bengkulu City provided by Bank Indonesia16.

The role of women in fishery economic activities is quite large ranging from preproduction, production, processing and marketing activities. In this case beperan as business actors and labor, especially in the processing and marketing sectors conducted in the realm of land in coastal areas. Fish processing is a secondary sector that is a series of activities and / or treatment of fish raw materials to be the final product for human consumption (Elucidation of Article 20 paragraph (1) of the Fisheries Law). In this sense fish processing as one of the food industry whose final product is a form of food product in the form of whole fish or products containing fish part. But the facts in the field of food products made from fish produced by women small micro business actors have not been able to grow and compete both in local, national and global markets due to various limitations.

Problems faced by women business actors in addition to capital difficulties, as well as issues related to knowledge of economic activities. Despite various empowerment and mentoring activities from several elements including Universities as the authors17 did, the efforts of women are still difficult to develop. The main thing is the absence of support from the government optimally. As said Rohmin Dahuri (2003: 13), that in the system of fishery business also needs to be supported by the sub-system of means of production that is infrastructure, financial, human resources, science and technology, law and institutional. Especially from the legal and institutional aspects of women's existence as business actors have not received attention, recognition and protection. Various relevant legislation such as Law no. 31 of 2004 and Law no. 45 Year 2009 on Fisheries, still focused on the male legal subjects of fishermen and fish farmers.

The ASEAN Economic Community (MEA) is a single market in Southeast Asia, aiming to increase foreign investment in Southeast Asia including
Indonesia which will also open the flow of easy trade in goods and services to Southeast Asian countries. In the agreement there are five things that should not be limited circulation in all ASEAN countries including Indonesia, namely the flow of goods, service flow, capital flow, investment flows and the flow of trained workers. In this situation the bets are competitiveness, both in terms of products and human resources, because if not prepared then there is a possibility this country will become a market of foreign products and our society just as spectators, because it is unable to compete with more skilled foreign workers. (DisperindagRI, 2015)

The global economy is a process of economic activity and trade activities there are many countries in the world that become one market power and increasingly integrated without the constraints or territorial boundaries of the country. The existence of this globalization of the economy means the necessity of the abolition of all restrictions and barriers to the flow of goods, services and capital. The embodiment of the global economy is in the form of globalization of production, financing, labor, information network and so on. These conditions can have a positive or negative impact on the national economy.18

MSMEs that are generally managed by women in principle have been able to contribute sufficiently to the national economy. However, by looking at the conditions as previously described, it will be difficult to compete in the global era. It is necessary to strengthen the efforts made by women both from human resources and institutional. Jurisdiction over human resources to fulfill women's basic rights should be a priority. It is in addition a form of recognition and protection (pengayoman) passive or active from the state. Passively it is to prevent arbitrary and violation of the right to women, and actively an effort to create conditions and encourage women business actors to always have confidence and improve their ability as a competitive business actor. In addition, the institutional to small and medium micro enterprises will provide legal certainty both bapak MSMEs itself and other parties who cooperate. Thus, micro, small and medium enterprises managed by women can develop and have bailing competitiveness at the local, national and global levels.

\section{CONCLUSION}

Referring to the description, it can be concluded that in the era of the global economy, there should be legal efforts provided and conducted by the state against women business actors. In addition to 
technically providing strengthening by empowerment in the field of financing, production, labor, technology and information and so on, as well as legal efforts to provide protection to women as business actors and institutional to business. The reinforcement is not only through government regulation but also implementation in giving basic rights to women and their business.

\section{Acknowledgments}

On this occasion the authors would like to thank the Directorate of Research and Community Service that has given the writer and team the opportunity to conduct research through the Competence Research Hibah Program (HIKOM). Also to the Rector of Bengkulu University, the Dean of the Faculty of Law of Bengkulu University through the Research Institute of UNIB provides an opportunity to carry out research. Likewise to all parties who have helped the implementation of research and writing this paper the authors thanks.

\section{REFERENCES}

[1] Ahmad Erani Yustika, Pembangunan dan Krisis (Memetakan Perekonomian Indonesia), Jakarta: PT Gramedia Widiasarana Indonesia (Grasindo), 2002, pp. 63-65.

[2] Dina Manafe, "80 persen UMKM di Indonesia dikelola Perempuan", Suara Pembaharuan, Senin, 25 Mei 2015, downloaded 5 Nopember 2017 from website

http://www.beritasatu.com/ekonomi/2768

06-80-umkm-di-indonesia-dikelolaperempuan.html

[3] Daniel Tempomona; Djuwita R.R. Aling Christian R. Dien, Peranan Perempuan Dalam Usaha Pengolahan Ikan Cakalang (Katsuwonus Pelamis L) Asap Di Kelurahan Girian Atas Kecamatan Girian Kota Bitung Provinsi Sulawesi Utara, Jurnal Vol. 5 No. 9 (April 2017) ISSN. 2337-4195, downloaded 13 Oktober 2017 from website https://media.neliti.com/media/publication s/135118 -ID-peranan-perempuan-dalamusaha-pengolahan.pdf.

[4] Fanesa Fargoneli, Interaksi Kelompok Nelayan Dalam Meningkatkan taraf Hidup di deasa Tewil Kecamatan sangaji Kabupaten Maba Halmahera Timur" Journal 'Acta Diurna' Volume III, No. 3 Tahun 2014, downloaded 12 October 2017 from website:

https://ejournal.unsrat.ac.id/index.php/act adiurna/ar ticle/view/5728

[5] Kompas, "Kontribusi UMKM Naik", downloaded $\quad 10 \quad$ Nopember 2017 dari http://www.kemenperin.go.id/artikel/1420 0/Kontri busi-UMKM-Naik

[6] Khoirul Lilabror, Strategi Pelaku Usaha Mikro, Kecil, dan Menengah (UMKM) Konveksi di Kota Semarang dalam Pasar Terbuka Masyarakat Ekonomi Asean (MEA) 2015 , Jurnal Ilmu Administrasi Bisnis, Volume. 6, Nomor 1, Tahun 2017, p. 3 downloaded website: http://ejournal3.undip.ac.id/index.php/jiab /article/vi ew/14566.

[7] Kementrian Kelautan dan Perikanan, "Laut Masa Depan Bangsa", downloaded 10 Nopember 2017 fromwebsite: feb.unair.ac.id/index.php/download/downl oad-materi-seminar.html?download.

[8] Kiara (Koalisi Rakyat Untuk Keadilan Perikanan), “Perempuan Nelayan Berhak Mendapatkan Perlindungan dan Pemberdayaan dari Negara", Kertas Kebijakan, Tahun 2015, downloaded 13 October 2017 from website https://www.kiara.or.id/wpcontent/upload s/2015/12/Kertas_Kebijakan_Perem puan_Nelayan_KIARA_151115.pdf.

[9] Nur Sulistyo B Ambarini, dkk, Pengembangan Model Perlindungan Hukum Bagi Perempuan Pelaku Usaha Perikanan Skala Mikro Dan Kecil Dalam Upaya Meningkatkan Daya Saing Produk, Bengkulu: Laporan Penelitian (unpublished), University of Bengkulu, 2015.

[10] Nur Sulistyo B Ambarini, dkk, Penguatan Kelembagaan UMKM Bidang Perikanan Masyarakat Pesisir, Bengkulu: Laporan Kegiatan Pengabdian Kepada Masyarakat (unpublished), University of Bengkulu, 2015.

[11] Nur Sulistyo B Ambarini, Perlindungan dan Pengembangan Usaha Mikro Kecil Bidang Perikanan Sebagai Upaya Pengendalian Pencemaran Wilayah Pesisir dan Laut, Jurnal Hukum Lingkungan, Vol.3 Issue 1, Juli 2016, p. 33.

[12] Prihatin Lumbanraja, "Bersama UKM Membangun Ekonomi Rakyat dan Lingkungan Hidup", Jurnal Ekonomi, Vol. 14 Nomor. 2, April 2011

[13] Philipus Hadjon, Perlindungan Hukum Bagi Rakyat di Indonesia, Sebuah Studi Tentang Prinsip-Prinsip, Penanganannya oleh 
Pengadilan Dalam Lingkungan Peradilan Umum dan Peradilan Administrasi Negara, Surabaya: PT. Bina IImu, Cet.1.

[14] Satjipto Rahardjo, Ilmu Hukum, Bandung: Penerbit PT Citra Aditya Bakti, cet ke-8, 2014.

[15] Soediman Kartohadiprodjo, Pancasila Sebagai Pandangan Hidup Bangsa Indonesia, Bandung: Gatra Pustaka, Cet.1, 2010.

[16] Sudikno, Mengenal Hukum (Suatu Pengantar), Yogyakarta: Liberty, Cet ke-4, 2008.

[17] Yuli Rahmini Suci, Perkembangan UMKM (usaha mikro kecil dan menengah) di Indonesia, Jurnal Ilmiah Cano Ekonomos Vol. 6 No. 1 Januari 2017, downloaded from website: http://ejournal.upp.ac.id/index.php/Cano/article/vi ew/1239 
